\title{
Anna Żelazna-Blicharz
}

Politechnika Lubelska

\section{BEZROBOCIE W RODZINIE A PROBLEM DZIEDZICZENIA BIEDY}

\section{PROBLEM BEZROBOCIA W POLSCE}

Zjawisko pozostawania bez pracy osób w wieku produkcyjnym jest powszechnym problemem wielu współczesnych społeczeństw, szczególnie na przełomie XX i XXI wieku. Towarzyszy wszelkim przemianom gospodarczym, a jego skala w zależności od fazy cyklu koniunkturalnego, podlega silnym wahaniom. W czasie kryzysu w latach 30 . XX wieku w niektórych krajach nawet co czwarty obywatel nie miał pracy (Skawińska, Sobiech, Nawrot 2008: 151), następnie przez blisko czterdzieści lat poziom bezrobocia kształtował się na niskim poziomie, by w latach dziewięćdziesiątych tegoż wieku szczególnie dotknąć kraje przechodzące transformację od gospodarki centralnie planowanej w kierunku gospodarki rynkowej.

Zjawisko bezrobocia ma znaczenie ekonomiczne, społeczne i polityczne. Definiując osoby bezrobotne podkreśla się zwykle trzy ich cechy: pozostawanie bez pracy, poszukiwanie pracy oraz gotowość do jej podjęcia (Kwiatkowski 2002: 13). Do bezrobotnych zalicza się osoby w wieku produkcyjnym, które są zdolne i gotowe do podjęcia pracy na typowych warunkach występujących w gospodarce oraz pozostają bez pracy, pomimo jej poszukiwania (Milewski red. 2001: 533).

Należy zauważyć, że obok aktywnych zawodowo, czyli zasobów siły roboczej (pracujących lub bezrobotnych) istnieje grupa osób biernych zawodowo, która także należy do grupy ludności w wieku produkcyjnym. Im wyższy współczynnik aktywności zawodowej, tym większa grupa ludności w wieku produkcyjnym chce pracować zawodowo (pracuje lub poszukuje pracy). Wysokość współczynnika zależy jednak od: poziomu i zmiany stawek płac, preferencji jednostek $\mathrm{w}$ zakresie kształcenia, modelu rodziny, liczby dzieci w rodzinie i sposobu ich wychowania oraz możliwości znalezienia pracy (Milewski 2001, s. 533).

W Polsce stopa bezrobocia od lat utrzymuje się na bardzo wysokim poziomie, w bieżącym 2014 roku wahała się od 14\% w styczniu do 12,5\% w maju. Najniższe wskaźniki miesięczne występowały w roku 2008 (tab. 1). 
Tabela 1. Stopa bezrobocia w Polsce w latach 2001-1013

\begin{tabular}{|l|c|c|c|c|c|c|c|c|c|c|c|c|c|}
\hline & 2001 & 2002 & 2003 & 2004 & 2005 & 2006 & 2007 & 2008 & 2009 & 2010 & 2011 & 2012 & 2013 \\
\hline I & 15,7 & 20,1 & 20,6 & 20,6 & 19,5 & 18,0 & 15,1 & 11,5 & 10,4 & 12,9 & 13,1 & 13,2 & 14,2 \\
\hline II & 15,9 & 20,2 & 20,7 & 20,6 & 19,4 & 18,0 & 14,8 & 11,3 & 10,9 & 13,2 & 13,4 & 13,4 & 14,4 \\
\hline III & 16,1 & 20,1 & 20,6 & 20,5 & 19,3 & 17,8 & 14,3 & 10,9 & 11,1 & 13,0 & 13,3 & 13,3 & 14,3 \\
\hline IV & 16,0 & 19,9 & 20,3 & 19,9 & 18,8 & 17,2 & 13,6 & 10,3 & 10,9 & 12,4 & 12,8 & 12,9 & 14,0 \\
\hline V & 15,9 & 19,2 & 19,8 & 19,5 & 18,3 & 16,5 & 12,9 & 9,8 & 10,7 & 12,1 & 12,4 & 12,6 & 13,5 \\
\hline VI & 15,9 & 19,4 & 19,7 & 19,4 & 18,0 & 16,0 & 12,3 & 9,4 & 10,6 & 11,7 & 11,9 & 12,3 & 13,2 \\
\hline VII & 16,0 & 19,4 & 19,6 & 19,3 & 17,9 & 15,7 & 12,1 & 9,2 & 10,7 & 11,5 & 11,8 & 12,3 & 13,1 \\
\hline VIII & 16,2 & 19,5 & 19,5 & 19,1 & 17,7 & 15,5 & 11,9 & 9,1 & 10,8 & 11,4 & 11,8 & 12,4 & 13,0 \\
\hline IX & 16,3 & 19,5 & 19,4 & 18,9 & 17,6 & 15,2 & 11,6 & 8,9 & 10,9 & 11,5 & 11,8 & 12,4 & 13,0 \\
\hline X & 16,4 & 19,5 & 19,3 & 18,7 & 17,3 & 14,9 & 11,3 & 8,8 & 11,1 & 11,5 & 11,8 & 12,5 & 13,0 \\
\hline XI & 16,8 & 19,7 & 19,5 & 18,7 & 17,3 & 14,8 & 11,2 & 9,1 & 11,4 & 11,7 & 12,1 & 12,9 & 13,2 \\
\hline XII & 17,5 & 20,0 & 20,0 & 19,1 & 17,6 & 14,9 & 11,2 & 9,5 & 11,9 & 12,4 & 12,5 & 13,4 & 13,4 \\
\hline
\end{tabular}

Źródło: Główny Urząd Statystyczny, www.stat.gov.pl.

Skutkibezrobociaokreślanesączęstojakospołeczno-psychologiczneimoralne. Negatywne efekty pozostawania bez pracy przejawiają się (Robak 2006: 248):

- poczuciem społecznej bezużyteczności, frustracji i depresji, potęgowanej przez postawy społeczeństwa, którego część przedstawicieli uważa bezrobotnych za ludzi leniwych i niechętnych do pracy;

- izolacją od środowiska społecznego, zdarza się, że bezrobotni zrywają kontakty towarzyskie i rodzinne;

- osłabieniem więzi międzyludzkich, uczuć rodzinnych, skłonnością do naruszania zasad współżycia społecznego, brakiem poszanowania dla przepisów prawa, zachowaniami aspołecznymi;

- przyjmowaniem postawy biernej, pasywnej, życiem na koszt społeczeństwa, wykorzystywaniem opieki społecznej i instytucji charytatywnych.

Utrata pracy oznacza uniemożliwienie zaspokojenia takich potrzeb, jak: działania $\mathrm{w}$ grupie, kontakty ze środowiskiem pozarodzinnym, wyznaczanie statusu i określanie tożsamości, ukierunkowanie aktywności, zorganizowanie struktury czasowej dnia i tygodnia. Ludzie bez pracy ograniczają wydatki, tracą kontakt z zapracowanymi krewnymi i znajomymi, popadają w przygnębienie, a swoją postawą bezsilności i bierności negatywnie oddziałują na swoje dzieci (Robak 2006: 249). Długotrwałe bezrobocie przyczynia się do braku równowagi psychicznej, utraty szacunku do samego siebie, degradacji kompetencji i motywacji, zwiększenia zachorowalności, a nawet przedwczesnej śmiertelności. Dzieci bezrobotnych często odtwarzają schemat życia swoich rodziców (Gazon 2008: 91). W rodzinach osób bezrobotnych występują liczne konflikty, pojawia się przemoc, zwiększa się liczba rozwodów. Długotrwałe bezrobocie rodziców zmniejsza szansę na powo- 
dzenie na rynku pracy ich dzieci, ponieważ mają w rodzinie kontakt z sytuacją ograniczeń czy braku pracy i przestają także same wierzyć w swoją dobrą sytuację na rynku pracy i lepszą przyszłość.

\section{UBÓSTWO W RODZINIE JAKO KONSEKWENCJA BEZROBOCIA}

Trudno jest jednolicie opisać „ludzi biednych”, jednak pewne kategorie ludzi popadają w ubóstwo częściej niż inne. $Z$ większym prawdopodobieństwem niż innych bieda dotyka właśnie osoby bezrobotne, pracujące w niepełnym wymiarze godzin oraz niemające uprawnień pracowniczych. Do grupy tej zalicza się również ludzi starszych, chorych, niepełnosprawnych, dzieci, kobiety i członków dużych rodzin (Giddens 2005: 337).

Dyskusja wokół rozumienia i pomiaru ubóstwa ma bogatą literaturę (Warzywoda-Kruszyńska W. red. 2012; Petelewicz, Warzywoda-Kruszyńska 2009; Grotowska-Leder 2010). R. Szarfenberg zauważa, że podstawą problemu w rozumieniu zjawiska ubóstwa jest nieprecyzyjne wyrażanie się i wymienia trzy sytuacje, o które może chodzić, gdy pojawia się słowo „ubóstwo” (Szarfenberg 2012):

- biologiczne ubóstwo (brakuje środków nawet na przeżycie w dobrym zdrowiu);

- społeczne ubóstwo (środki są wystarczające do przeżycia, ale brakuje ich do uczestnictwa w społeczeństwie);

- relatywne ubóstwo (środków nie wystarcza na to, na co stać większość ludzi w danym społeczeństwie czy społeczności, ale umożliwiają przeżycie i uczestnictwo w społeczeństwie).

Miejsce zajmowane na rynku pracy jest czynnikiem decydującym o statusie społecznym, sytuacji materialnej jednostki i jej rodziny. Obecnie ważnym czynnikiem powodującym ubóstwo jest bezrobocie długoterminowe, trwające dłużej niż dwanaście miesięcy (Szacka 2003: 341). W 2012 roku wśród gospodarstw domowych, w skład których wchodziła przynajmniej jedna osoba bezrobotna stopa ubóstwa skrajnego wynosiła ok. 13\%, podczas gdy wśród gospodarstw, w których nie było osób bezrobotnych - ok. 5\%. Większa liczba osób bezrobotnych w gospodarstwie domowym znacząco zwiększa ryzyko ubóstwa skrajnego. W gospodarstwach domowych, w których bezrobotne były przynajmniej dwie osoby stopa ubóstwa skrajnego wynosiła ok. 33\% (Ubóstwo w Polsce w świetle badań..., 2013: 13).

Podział biedy na stare i nowe ubóstwo umożliwia wyodrębnienie jego przyczyn. Stara bieda wynika z przyczyn niezamierzonych, zdarzających się w każdym typie społeczeństwa (niemożność zarobkowania wskutek kalectwa, długotrwałej choroby, podeszłego wieku, wielodzietności), natomiast nowa bieda wywołana jest przemianami w gospodarce (globalizacją, restrukturyzacją), 
które przyczyniają się do utraty pracy przez osoby fizycznie i psychicznie zdolne do pracy (Warzywoda-Kruszyńska 1999: 14). Stosowanych jest wiele metod pomiaru ubóstwa, w tab. 2 zostały przedstawione kryteria zgodne z wytycznymi krajowymi oraz wykorzystywanymi na poziomie Unii Europejskiej.

Tabela 2. Granice ubóstwa stosowane w Polsce w latach 1990-2011

\begin{tabular}{|l|l|}
\hline \multicolumn{1}{|c|}{ Wytyczne polskie } & \multicolumn{1}{c|}{ Wytyczne według Eurostatu } \\
\hline Minimum socjalne & $60 \%$ mediany dochodów, \\
\hline Minimum egzystencji & $\begin{array}{l}\text { Co najmniej 4 potrzeby z 9, na których zaspoko- } \\
\text { jenie nie stać gospodarstwa domowego }\end{array}$ \\
\hline $50 \%$ średnich wydatków, & \\
\hline $\begin{array}{l}\text { subiektywna granica ubóstwa (na podstawie do- } \\
\text { chodów), }\end{array}$ & \\
\hline $\begin{array}{l}\text { Kryterium dochodowe z ustawy o pomocy spo- } \\
\text { łecznej (tzw. linia oficjalna) }\end{array}$ & \\
\hline
\end{tabular}

Źródło: Szarfenberg (2012).

W szacowaniu skali ubóstwa powszechnie stosowane są dwie koncepcje: podejście absolutne i względne (relatywne). Zgodnie z pierwszą ubogie są te gospodarstwa domowe lub osoby, które nie mają możliwości zaspokojenia potrzeb uznanych w danych warunkach za podstawowe - wystarczająca ilość pożywienia, schronienie i ubranie. W podejściu drugim ubóstwo rozważane jest jako forma nierówności, nadmiernego dystansu pomiędzy poziomem życia poszczególnych grup ludności. Za ubogie traktuje się osoby i rodziny, których poziom życia jest niższy niż przeciętnie w populacji. W badaniach ubóstwa obiektywnego za syntetyczną miarę dobrobytu ekonomicznego gospodarstwa domowego przyjęto poziom wydatków (Giddens 2005; GUS). Gospodarstwo domowe i wszystkie osoby wchodzące w jego skład, zostają uznane za ubogie lub zagrożone ubóstwem, jeżeli poziom jego wydatków (łącznie z wartością artykułów otrzymanych nieodpłatnie oraz pobranych z indywidualnego gospodarstwa rolnego, działki bądź z prowadzonej działalności na własny rachunek) jest niższy od wartości przyjętej za granicę ubóstwa na podstawie cen produktów niezbędnych do życia w danym kraju. Przy czym w wyznaczaniu granic ubóstwa w badaniach GUS obowiązują dwie wielkości progowe: dla osoby samotnie gospodarującej (gospodarstwo jednoosobowe) oraz dla osoby w rodzinie (bez względu na wiek osób). Od października 2006 roku dla osoby samotnie gospodarującej jest to kwota 477 złotych, zaś dla osoby w gospodarstwie wieloosobowym - 351 złotych (Ubóstwo w Polsce w 2011 roku).

GUS prowadzi także badania ubóstwa zgodnie z metodologią Eurostatu, na podstawie Europejskiego Badania Warunków Życia Ludności (EU-SILC), w których stosuje się kilka wskaźników jego występowania (wskaźnik zagroże- 
nia ubóstwem lub wykluczeniem społecznym, a także wskaźnik zagrożenia ubóstwem po uwzględnieniu transferów społecznych, wskaźnik osób zagrożonych pogłębioną deprywacją materialną oraz wskaźnik osób żyjących w gospodarstwach domowych o niskiej intensywności pracy). $Z$ analiz tych, przy zastosowaniu wskaźnika nierówności społecznej, inaczej wskaźnika Giniego, który wyraża nierównomierny rozkład dochodów w gospodarstwach domowych ${ }^{1}$ wynika, że przez wiele ostatnich lat był on w Polsce wyższy niż średnio w UE, ale systematycznie spadał i w 2011 roku zbliżył wartość do średniej w UE - odpowiednio 31,1 i 30,7 (wykres 1 ).

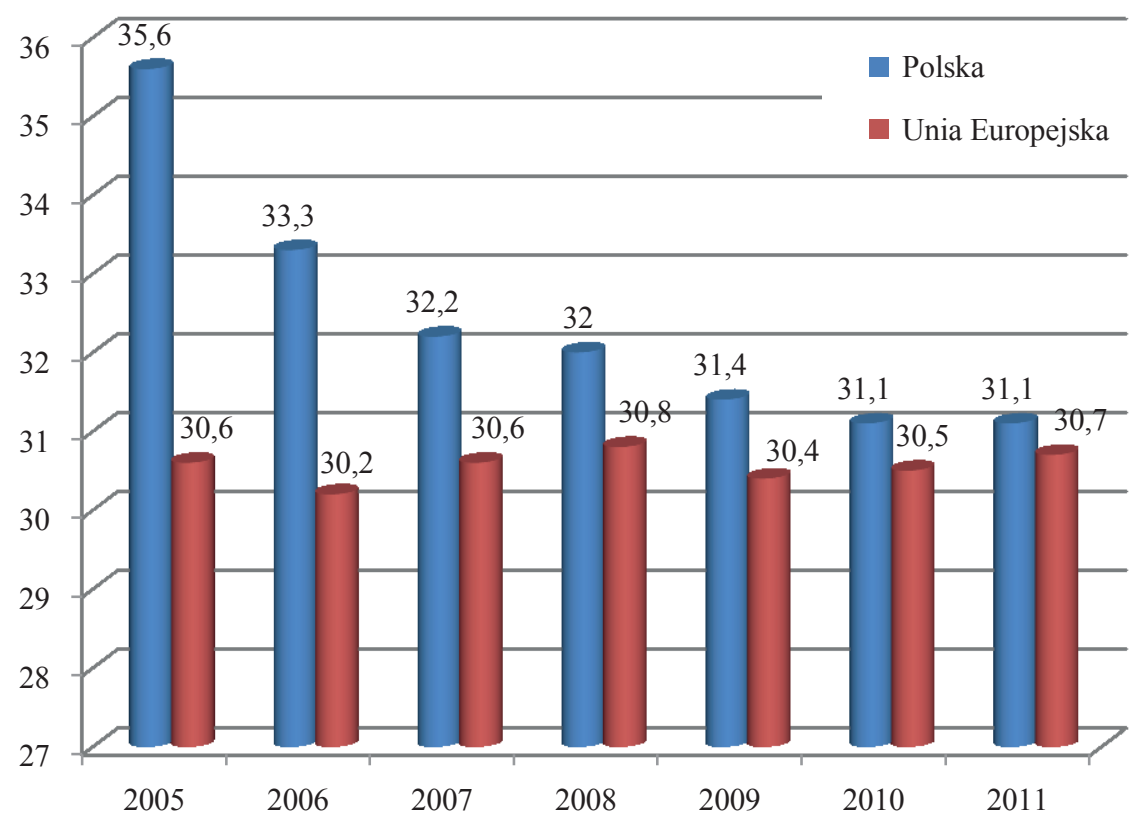

Wykres 1. Współczynnik Giniego w Polsce i Unii Europejskiej w latach 2005-2011 Źródło: Dochody i warunki życia ludności Polski (raport z badania EU-SILC 2011), GUS, Warszawa 2012, s. 158.

Charakterystyki osób biednych w Polsce i tym samym uwarunkowania niekorzystnej sytuacji materialnej Polaków wskazują na istotne prawidłowości. Badania GUS wykazały, że najwyższy wskaźnik zagrożenia ubóstwem po uwzględnieniu w dochodach transferów społecznych występuje w grupie osób bezrobotnych

${ }^{1} \mathrm{Za}$ gospodarstwo domowe uznawana była grupa osób spokrewnionych ze sobą lub niespokrewnionych, mieszkających razem i wspólnie utrzymujących się (gospodarstwo domowe wieloosobowe) lub osobę utrzymującą się samodzielnie, bez względu na to czy mieszka sama, czy $\mathrm{z}$ innymi osobami (gospodarstwo domowe jednoosobowe).. 
i wynosi 43,6\% (tab. 3). W grupie bezrobotnych mężczyzn wskaźnik ten wyniósł $49,7 \%$, natomiast wśród bezrobotnych kobiet plasował się na poziomie $38,1 \%$ (Dochody i warunki życia ludności Polski).

Tabela 3. Wskaźniki zagrożenia ubóstwem w Polsce w 2011 roku

\begin{tabular}{|l|c|c|c|}
\hline \multirow{2}{*}{$\begin{array}{c}\text { Kategorie } \\
\text { społeczne }\end{array}$} & $\begin{array}{c}\text { po uwzględnieniu } \\
\text { w dochodach } \\
\text { transferów } \\
\text { społecznych* }\end{array}$ & $\begin{array}{c}\text { Wskaźnik zagrożenia ubóstwem } \\
\text { bez uwzględnienia w dochodach } \\
\text { transferów społecznych innych } \\
\text { niż renty i świadczenia związane } \\
\text { z wiekiem* }\end{array}$ & $\begin{array}{c}\text { bez uwzględnienia } \\
\text { w dochodach } \\
\text { ogółu transferów } \\
\text { społecznych* }\end{array}$ \\
\hline Ogółem & $\mathbf{1 7 , 7}$ & $\mathbf{2 4 , 1}$ & $\mathbf{4 3 , 4}$ \\
\hline do 17 lat & 22 & 30 & 36,7 \\
\hline 18-64 lata & 17,1 & 23,8 & 37 \\
\hline powyżej 65 lat & 14,7 & 17,3 & 84 \\
\hline $\begin{array}{l}\text { Mężczyźni } \\
\text { ogółem }\end{array}$ & $\mathbf{1 7 , 8}$ & $\mathbf{2 4 , 4}$ & $\mathbf{4 1 , 4}$ \\
\hline 18-64 lata & 17,6 & 24,5 & 36,2 \\
\hline powyżej 65 lat & 10,2 & 12,2 & 83,7 \\
\hline Kobiety ogółem & $\mathbf{1 7 , 6}$ & $\mathbf{2 3 , 9}$ & $\mathbf{4 5 , 2}$ \\
\hline 18-64 lata & 16,5 & 23,2 & 37,8 \\
\hline powyżej 65 lat & 17,4 & 20,4 & 84,2 \\
\hline Pracujący & $\mathbf{1 1 , 1}$ & - & - \\
\hline Bezrobotni & $\mathbf{4 3 , 6}$ & - & - \\
\hline Emeryci & $\mathbf{1 3 , 2}$ & - & - \\
\hline $\begin{array}{l}\text { Pozostali } \\
\text { nieaktywni } \\
\text { zawodowo }\end{array}$ & $\mathbf{2 6 , 8}$ & - & - \\
\hline
\end{tabular}

*W odniesieniu do 2010 roku.

Źródło: opracowanie własne na podstawie Dochody $i$ warunki życia ludności Polski (raport z badania EU-SILC 2011), GUS, Warszawa 2012, s. 145-146.

Inne wysokie wskaźniki zagrożenia ubóstwem występują także w przypadku gospodarstw:

- złożonych z 2 dorosłych z trojgiem i większą liczbą dzieci na utrzymaniu $(34,6 \%)$;

- złożonych z rodzica i przynajmniej jednego dziecka na utrzymaniu (29,8\%);

- jednoosobowych ogólem $(25,5 \%)$, przy czym w grupie mężczyzn prowadzących jednoosobowe gospodarstwa domowe wynosi on $31,6 \%$, a w przypadku kobiet $-22,7 \%$.

Wskaźnik zagrożenia ubóstwem w Polsce, po uwzględnieniu w dochodach transferów społecznych, w 2011 roku w stosunku do roku 2010 wyniósł 17,7\%. Dokonując analizy tego wskaźnika w ostatnich latach można zauważyć jego wzrost 
od 2008 roku (w 2008 wyniósł 16,9\%, w 2009 - 17,1\%, w 2010 - 17,6\%). W latach 2005-2007 zaobserwowano jego spadku (w 2005 znajdował się na poziomie 20,5\%, w 2006 - 19,1\%, a rok później 17,3\%) (Dochody $i$ warunki życia ludności Polski).

Od lat ubóstwem zagrożone są przede wszystkim osoby i rodziny osób bezrobotnych. W 2011 roku w gospodarstwach domowych, w których co najmniej jedna osoba pozostawała bez pracy zagrożonych ubóstwem ustawowym było około 11,5\% osób, a w gospodarstwach z dwoma i więcej osobami bezrobotnymi problem ten dotyczył niemal co trzeciej osoby. Z kolei w gospodarstwach bez osób bezrobotnych jedynie co dwudziesta osoba żyła poniżej granicy ubóstwa ustawowego (Ubóstwo w Polsce w 2011 r.).

\section{MIĘDZYPOKOLENIOWE DZIEDZICZENIE UBÓSTWA JAKO KONSEKWENCJA BEZROBOCIA}

Sytuacja, z którą dzieci stykają się w gospodarstwach domowych przekłada się na ich dalsze życie. Potwierdzają to badania prowadzone przez GUS w 2011 roku dotyczące międzypokoleniowego dziedziczenia niekorzystnych sytuacji życiowych (Dochody $i$ warunki życia ludności Polski). Wynika z nich, że najwięcej osób zagrożonych pogłębioną deprywacją materialną pochodzi z gospodarstw domowych bez rodziców $(44,3 \%$ badanych) lub gospodarstw zbiorowych $(54,2 \%)$. $\mathrm{Z}$ problemem deprywacji materialnej boryka się aż 44,1\% badanych, którzy sytuację finansową osób, z którymi zamieszkiwali w wieku 14 lat, określali jako bardzo złą. Niewiele mniej (40,4\%) osób z tym problemem sytuację określiło jako złą. Widoczna jest też zależność pomiędzy obecnym poziomem wykształcenia badanej osoby w wieku 25-59 lat a jej sytuacją w gospodarstwie domowym, gdy była w wieku 14 lat. Wyższe wykształcenie osiągnęło aż 37,7\% osób z gospodarstw domowych, których sytuacja określona została jako bardzo dobra, 34,4\% z sytuacją dobrą, ale tylko $9,9 \%$ badanych z gospodarstw domowych z sytuacją bardzo złą i $10,1 \%$ z sytuacją złą. Dzieci z gospodarstw domowych z sytuacją złą lub bardzo złą zdecydowanie częściej edukację kończyły osiągając wykształcenie zasadnicze (odpowiednio: 26,7\% i 45,5\%) lub średnie (odpowiednio: 25\% i $41 \%$ ). Widoczna jest także zależność pomiędzy poziomem wykształcenia rodziców, gdy badani mieli 14 lat, a obecnym poziomem wykształcenia respondentów. Dzieci, których rodzice mieli wyższe wykształcenie aż w 65,9\% także uzyskały wykształcenie wyższe, natomiast fakt niskiego poziomu wykształcenia rodziców przełożył się na wykształcenie zasadnicze zawodowe ich dzieci $(43,6 \%$ badanych) i średnie (30,6\%).

Ubóstwo w młodym wieku nie tylko wpływa na trudniejszy start w dorosłe życie poprzez często ograniczony dostęp do wiedzy, nowych technologii, ale także kształtuje sposób myślenia, postrzegania świata i ludzi oraz własnej roli 
na rynku pracy w przyszłości. Ubóstwo może przyczynić się do izolacji społecznej, utrwalania się takiej sytuacji, a nawet przekazywania jej z pokolenia na pokolenie. Szczególnie powiększająca się sfera ubóstwa niesie wiele zagrożeń, wśród nich (Sadowska-Snarska 2001: 241):

- wzrost zjawisk patologii społecznej (przestępczość przeciw mieniu i życiu, alkoholizm i narkomania);

- wzrasta liczba beneficjentów zinstytucjonalizowanej pomocy społecznej;

- narasta zjawisko utraty zdolności do utrzymania mieszkania, czego efektem jest rosnąca liczba bezdomnych;

- ograniczony dostęp do ochrony zdrowia wpływa niekorzystnie na kondycję zdrowotną wielu grup społecznych;

- bariery w dostępie do edukacji ze względów finansowych powodują „dziedziczenie" ubóstwa.

Badania empiryczne prowadzone $\mathrm{w}$ krajach stanowią potwierdzenie, że w grupie osób ubogich spożycie alkoholu jest wyższe niż wśród osób zamożnych, a poważne uzależnienie od alkoholu częściej dotyczy osób znajdujących się w skrajnej biedzie (Kurowska 2008: 16-17). Problemy te wykazały również badania prowadzone w łódzkich enklawach biedy w grupie osób zagrożonych ubóstwem i wykluczeniem społecznym w cyklu życia oraz w międzypokoleniowym przekazie (Jankowski, Warzywoda-Kruszyńska 2010).

\section{POLITYKA WALKI Z BEZROBOCIEM I UBÓSTWEM JAKO JEGO KONSEKWENCJA}

Na szczeblu UE podjęto walkę z ekskluzją społeczną powodowaną w głównej mierze ubóstwem. Priorytety przyjęte przez Radę Europejską, przełożyły się na cztery główne zasady działania (Głąbicka 2006: 223-225):

- przedsiębiorczość, czyli działanie na rzecz promocji nowej kultury przedsiębiorczości w Europie;

- tworzenie nowej kultury zatrudnienia, którą kreować można poprzez kwalifikacje umożliwiające znalezienie pracy;

-zdolność adaptacji poprzez promowanie nowoczesnych metod organizacji pracy;

- politykę na rzecz równości szans kobiet i mężczyzn poprzez zwiększanie udziału kobiet na rynku pracy i przełamanie segregacji płciowej, godzenie pracy z życiem rodzinnym, ułatwianie powrotu do pracy po dłuższej przerwie.

Polska polityka rynku pracy stanowi całokształt działań podejmowanych przez aparat administracji rządowej i samorządowej $\mathrm{z}$ zastosowaniem instrumentów prawnych, ekonomicznych i społecznych, których celem jest osiągnięcie, uznanego za zadowalający, poziom zatrudnienia i bezrobocia (Kwiatkowski 2002). Podejmowane są działania interwencyjne na rynku pracy $z$ wykorzysta- 
niem środków publicznych, w zakresie promocji zatrudnienia, łagodzenia skutków bezrobocia oraz aktywizacji zawodowej. Obok publicznych służb zatrudnienia do instytucji rynku pracy zalicza się ochotnicze hufce pracy, agencje zatrudnienia, instytucje szkoleniowe, instytucje dialogu społecznego, instytucje partnerstwa lokalnego.

Do najczęściej praktykowanych form pasywnej polityki państwa na rynku pracy należą różne formy pomocy finansowej dla bezrobotnych, wśród nich: zasiłki dla bezrobotnych, odszkodowania dla osób zwalnianych z pracy i dodatki związane z wcześniejszym przechodzeniem na emeryturę. Zasiłki dla bezrobotnych mają na celu skompensowanie utraty dochodu $\mathrm{z}$ tytułu pracy, złagodzenie czasu po utracie zatrudnienia oraz częściowe zmniejszenie nierówności wywołanych przez funkcjonowanie rynku pracy (Gazon 2008: 48). Obecnie wartość podstawowego zasiłku dla bezrobotnych wypłacanego przez pierwsze trzy miesiące po utracie pracy wynosi $823,60 \mathrm{zl}$, a w kolejnych miesiącach $-646,70 \mathrm{zl}^{2} \mathrm{Im}$ dłuższy okres braku pracy i zbliżona wartość zasiłku dla bezrobotnych do kwoty możliwej do wynegocjowania zapłaty za pracę, tym mniejsza motywacja bezrobotnego do podjęcia zatrudnienia. Zaczyna on wieść życie bezrobotnego i organizuje swoją bezczynność. Zasiłki dla bezrobotnych powodują także nacisk na wzrost wynagrodzeń pracowników w czasie negocjacji płacowych, których celem jest zwiększenie różnicy pomiędzy negocjowanym wynagrodzeniem i płacą zastępczą, czyli zasiłkiem dla bezrobotnych (Gazon 2008: 49).

Część osób pozostających bez pracy, która nie spełnia warunków, aby otrzymywać zasiłek dla bezrobotnych, pobiera zasiłki pomocy socjalnej. Im bardziej świadczenia socjalne są zbliżone do kwoty zasiłku dla bezrobotnych, tym mniejsza motywacja, żeby szukać pracy. W przypadku znalezienia pracy, a następnie jej utraty osobom pobierającym wcześniej zasiłki z pomocy społecznej, przysługuje ponownie zasiłek dla bezrobotnych.

Bezrobotni mogą także pozyskać środki na podjęcie działalności gospodarczej oraz wyposażenie stanowiska pracy (nawet w kwocie 21 061,32 zł), a także dostać pożyczkę na sfinansowanie kosztów szkolenia z Funduszu Pracy. Wymagane jest jednak zawarcie umowy z powiatowym urzędem pracy ${ }^{3}$.

W ramach walki o wyjście $\mathrm{z}$ ubóstwa rola państwa powinna polegać na: pomocy ludności w zaspokajaniu podstawowych potrzeb, zapewnieniu żywności, wody zdatnej do picia, dostępu do służby zdrowia oraz inwestycjach w infrastrukturę i rolnictwo, aby stworzyć podstawy wzrostu gospodarczego. Dyskusja o zasięgu i wielkości pomocy społecznej trwa nadal i nasila się wraz z globalizacją (Sachs 2009: 249-251). Polityka państwa może wpływać na wysokość dochodów gospodarstw domowych i w efekcie pośrednio oddziaływać na poziom

${ }^{2}$ Portal Publicznych Służb Zatrudnienia, Ministerstwo Pracy i Polityki Społecznej, http:// www.psz.praca.gov.p1/ (odczyt 1.09.2013).

3 Departament Funduszy MPiPS (odczyt 10.12.2012). 
ubóstwa (Bukowski, Magda 2013: 157-161). Do takich instrumentów należą świadczenia (np. system świadczeń rodzinnych, dodatków mieszkaniowych, świadczeń z pomocy społecznej i świadczeń dla bezrobotnych) oraz regulacje obciążeń podatkowych (elementy redukujące wysokość płaconego podatku dochodowego, skala progresji podatkowej). Polityka państwa w latach 2005-2010 przyczyniła się do obniżenia ubóstwa wśród dzieci (o 1,4\%), ale stopień wsparcia rodzin z dziećmi w Polsce w ramach świadczeń socjalnych nadal należy do najniższych w Europie (Bukowski, Magda 2013: 180). Istnieje jednak konieczność podejmowania działań, które skierowane są do dzieci i młodzieży. Wyzwanie stanowi wyrównywanie szans najmłodszych w dostępie do edukacji, umożliwianie im jak najszerszego dostępu do szkolnictwa na wysokim poziomie, eliminowanie ograniczania aspiracji edukacyjnych z powodu trudności materialnych rodziców. Ważnym programem zapewniającym dofinansowanie zakupu podręczników, z którego w 2013 roku skorzysta około 28\% dzieci rozpoczynających naukę w klasach pierwszych (ponad 575 tys. uczniów) jest Wyprawka Szkolna. Dla uczniów klas pierwszych szkoły podstawowej oraz artystycznej dochód graniczny kwalifikujący do uzyskania wsparcia wynosi 539 zł netto na osobę w rodzinie (jest to kryterium określone w ustawie o świadczeniach rodzinnych). Uczniowie pozostałych klas, którzy mogą uczestniczyć w programie, muszą wykazać, że dochód na osobę w rodzinie nie przekracza 456 zł netto (kryterium z ustawy o pomocy społecznej) ${ }^{4}$. Potrzeby edukacyjne dzieci w rodzinach z tak niskimi dochodami odsuwane są na dalszy plan, a w konsekwencji często pozostają niezaspokojone.

Coraz częściej podejmowane są działania nie tylko przez publiczne instytucje rynku pracy, ale również organizacje pozarządowe, w celu wspierania i aktywowania grup uważanych na rynku pracy za wykluczone (tab. 4). Określa się je także jako ,grupy defaworyzowane”. Są to grupy osób związanych z tzw. „wtórnym” (drugorzędnym) rynkiem pracy, gdzie fluktuacja zatrudnienia jest bardzo wysoka, warunki pracy (wynagrodzenie, podnoszenie kwalifikacji) zdecydowanie gorsze, a okresy bezrobocia częstsze (wielokrotne bezrobocie) lub dłużej trwające (długotrwałe bezrobocie $)^{5}$. Do grup defaworyzowanych zalicza się całe grupy społeczne, jak młodzież lub osoby borykające się z bardzo specyficznymi problemami (np. osoby opuszczające zakłady karne).

Skuteczna strategia przeciwdziałania zjawisku dziedziczenia biedy (wykluczenia społecznego) wymaga efektywnej współpracy wszystkich miejskich służb i koncentracji wsparcia finansowego, co umożliwi przejście od ,zarządzania biedą" do realizacji strategii rozwiązywania problemów społecznych. Właściwa wydaje się także współpraca $\mathrm{z}$ organizacjami pozarządowymi w realizacji zadań pomocy społecznej (Jankowski., Warzywoda-Kruszyńska 2010: 46).

\footnotetext{
${ }^{4}$ http://www.men.gov.pl (odczyt 28.09.2013).

${ }^{5}$ http://bezrobocie.org.pl/ (odczyt 15.09.2013).
} 
Tabela 4. Instytucje specjalizujące się w aktywizacji poszczególnych grup na rynku pracy

\begin{tabular}{|l|l|}
\hline \multicolumn{1}{|c|}{$\begin{array}{c}\text { Defaworyzowane grupy } \\
\text { na rynku pracy }\end{array}$} & \multicolumn{1}{|c|}{ Instytucje wspierające i aktywizujące } \\
\hline Młodziez & $\begin{array}{l}\text { powiatowe urzędy pracy } \\
\text { centra informacji i planowania kariery zawodowej } \\
\text { gminne centra informacji } \\
\text { akademickie biura karier } \\
\text { kluby prac } \\
\text { centra edukacji i pracy młodzieży } \\
\text { mobilne centra informacji zawodowej } \\
\text { instytucje niepubliczne }\end{array}$ \\
\hline $\begin{array}{l}\text { Osoby powyżej 50-tego } \\
\text { roku życia }\end{array}$ & $\begin{array}{l}\text { organizacje pozarządowe } \\
\text { uniwersytety trzeciego wieku }\end{array}$ \\
\hline $\begin{array}{l}\text { Mieszkańcy obszarów } \\
\text { wiejskich }\end{array}$ & $\begin{array}{l}\text { powiatowe urzędy pracy } \\
\text { samorządy (gminy wiejskie) } \\
\text { gminne centra informacji } \\
\text { ochotnicze hufce pracy } \\
\text { organizacje pozarządowe }\end{array}$ \\
\hline Osoby niepełnosprawne & $\begin{array}{l}\text { organizacje pozarządowe } \\
\text { Biuro Karier i Agencja Pośrednictwa Pracy dla Osób } \\
\text { Niepełnosprawnych } \\
\text { Państwowy Fundusz Rehabilitacji Osób Niepełnosprawnych }\end{array}$ \\
\hline Bezdomni & $\begin{array}{l}\text { organizacje pozarządowe } \\
\text { ośrodki pomocy społecznej } \\
\text { urzędy pracy }\end{array}$ \\
\hline
\end{tabular}

Źródło: opracowanie własne na podstawie: Werbanowska (2006); Schimanek (2006); Marchlewski (2006); Olech (2006).

\section{ZAKOŃCZENIE}

Bezrobocie może przyczyniać się do negatywnych zjawisk, jak ubóstwo i marginalizacja. Stanowią one zróżnicowane i wieloaspektowe problemy, które wpływają nie tylko na jakość egzystencji gospodarstwa domowego, ale także mogą przekładać się na zachowania dzieci i rodziny zakładane przez nie w wieku dorosłym. Z mechanizmem dziedziczenia ubóstwa wiąże się także „wyuczona bezradność", która charakteryzuje się przekonaniem jednostki, że bez względu na to jak będzie działać i jakie decyzje podejmować, nie jest w stanie zmienić swojego położenia. Rolą instytucji publicznych i organizacji pozarządowych jest wspieranie i aktywizowanie osób z problemem bezrobocia w celu właściwego ukierunkowania oraz jak najszybszego powrotu na rynek pracy. 


\section{BIBLIOGRAFIA}

Bukowski M., Magda I. (red.) (2013), Zatrudnienie w Polsce 2011. Ubóstwo a praca. Państwo i nierówności - polityka publiczna wobec problemu ubóstwa i wykluczenia, Instytut Badań Strukturalnych, Warszawa.

Dochody i warunki życia ludności Polski (raport z badania EU-SILC 2011) (2012), GUS, Warszawa.

Gazon J.(2008), Ani bezrobocie, ani opieka społeczna. Od wyboru etycznego do ekonomicznej realizacji, Wydawnictwo Naukowe PWN, Warszawa.

Giddens A. (2005), Socjologia, Wydawnictwo Naukowe PWN, Warszawa.

Głąbicka K.(2006), Socjalny wymiar Europy. Od niewolnictwa do obywatelskości, Wydawnictwo Politechniki Radomskiej, Radom.

Grotowska-Leder J. (2010), Ubóstwo w Polsce w okresie transformacji-aspekty teoretyczne i empiryczne, [w:] Społeczeństwo wobec wyzwań wspótczesności. Wybrane podejścia badawcze i interpretacyjne, Wydawnictwo Uniwersytetu Łódzkiego, Łódź.

Jankowski B., Warzywoda-Kruszyńska W. (2010), Mieszkańcy łódzkich enklaw biedy 10 lat później, Raport z projektu zrealizowanego przez Uniwersytet Łódzki w partnerstwie z Fundacją Instytut Inicjatyw Społecznych, Łódź.

Kurowska A. (2008), Ską się bierze bieda? Zeszyt 5, Forum Obywatelskiego Rozwoju, Warszawa,

Kwiatkowski E. (2002), Bezrobocie. Podstawy teoretyczne, Wydawnictwo Naukowe PWN, Warszawa.

Marchlewski W. (2006), Działalność organizacji pozarządowych świadczacych usługi na rynku pracy skierowane do mieszkańców obszarów wiejskich, Fundacja Inicjatyw Społeczno-Ekonomicznych, Warszawa.

Milewski R.(2001), Podstawy ekonomii, Wydawnictwo Naukowe PWN, Warszawa.

Olech P.(2006), Aktywizacja zawodowa osób bezdomnych, Fundacja Inicjatyw Społeczno-Ekonomicznych, Warszawa.

Petelewicz M., Warzywoda-Kruszyńska W. (2009), Bieda $w$ dzieciństwie jako zagrożenie bieda $i$ wykluczeniem społecznym w przyszłości, Wydawnictwo Biblioteka, Łódź.

Robak E. (2006), Społeczne koszty bezrobocia a przedsiębiorstwo, [w:] J. Chluska (red.), Kosztowe aspekty zarzązania, Wydawnictwo Politechniki Częstochowskiej, Częstochowa.

Sachs J.(2009), Nasze wspólne bogactwo. Ekonomia dla przeludnionej planety, Wydawnictwo Naukowe PWN, Warszawa.

Sadowska-Snarska C.(2001), Społeczne aspekty polityki dochodowej w Polsce, [w:) R. Horodeński, E. Ozorowski (red.), Człowiek Etyka. Ekonomia, Wydawnictwo Wyższej Szkoły Ekonomicznej w Białymstoku, Białystok.

Schimanek T.(2006), Sytuacja osób powyżej 50-tego roku życia na rynku pracy oraz rola organizacji pozarządowych świadczących ustugi rynku pracy skierowane do tych osób, Fundacja Inicjatyw Społeczno-Ekonomicznych, Warszawa 2006.

Skawińska E. Sobiech K.G., Nawrot K.A. (2008), Makroekonomia, Polskie Wydawnictwo Ekonomiczne, Warszawa.

Szacka B. (2003), Wprowadzenie do socjologii, Oficyna Naukowa, Warszawa .

Szarfenberg R., Ubóstwo i wykluczenie społeczne w Polsce - pomiar, wyjaśnianie, strategie przeciwdziałania, wersja 1.1, 20.11.12, na zamówienie Fundacji im. Friedricha Eberta, http:// rszarf.ips.uw.edu.pl/pdf/uiws2012a.pdf

Ubóstwo w Polsce w 2011 r. (na podstawie badań budżetów gospodarstw domowych), Główny Urząd Statystyczny, Departament Badań Społecznych i Warunków Życia (materiał na konferencję prasową, 31.05.2012 r.).

Ubóstwo w Polsce w świetle badań GUS, Studia i analizy statystyczne, Główny Urząd Statystyczny, Departament Badań Społecznych i Warunków Życia, Urząd Statystyczny w Łodzi, Warszawa 2013. 
Warzywoda-Kruszyńska W. (2012), Bieda dzieci. Zaniedbanie, wykluczenie społeczne, Wydawnictwo Uniwersytetu Łódzkiego, Łódź.

Warzywoda-Kruszyńska W., (Żyć) na marginesie wielkiego miasta, Instytut Socjologii, Łódź.

Werbanowska J.(2006), Problematyka organizacji pozarzadowych jako ustugodawców dla młodzieży na rynku pracy, Fundacja Inicjatyw Społeczno-Ekonomicznych, Warszawa.

www.men.gov.pl.

www.stat.gov.pl.

\section{Streszczenie}

Problem bezrobocia ciągle poważnym doświadczeniem dla tysięcy rodzin w Polsce, który dokumentują dan GUS. Bezrobocie, szczególnie długotrwałe, młody wiek, niski poziom wykształcenia, fakt zamieszkiwania na wsi lub w małym mieście zwiększają prawdopodobieństwo ubóstwa. Długotrwałe bezrobocie przyczynia się do bierności nie tylko zawodowej, ale także społecznej, zaniżonego poczucia własnej wartości i bezpieczeństwa, marginalizacji społecznej. Następstwem jest wieloaspektowy negatywny wpływ na wszystkich członków rodziny. Celem autorki artykułu jest ukazanie obecnej sytuacji na rynku pracy i wpływu bezrobocia na problem dziedziczenia ubóstwa, a także możliwych instytucji wspierających i aktywizujących grupy uważane za wykluczone na rynku pracy. Różne formy aktywizacji mogą przeciwdziałać pozostawaniu bezrobotnym lub biernym na rynku pracy, a w konsekwencji zapewnić wyjście z ubóstwa i zwiększyć kontrolę nad własnym życiem.

Słowa kluczowe: bezrobocie, ubóstwo.

\section{Unemployment in a family and the problem of transmission of poverty}

\section{Summary}

Problem of unemployment is still major for thousands of families in Poland according to data released by the Central Statistical Office. Unemployment, particularly long-term, young age, low education level, the fact of living in a village or a small town increase the likelihood of poverty. Long-term unemployment contributes to inactivity not only professional, but also social, understated sense of self-worth and security, social marginalization. The consequence is a multi-faceted negative impact on all family members. The purpose of this article is to present the current situation in the labour market and the impact of unemployment on the problem of poverty and possible support institutions and institutions activating groups deemed to be excluded in the labour market. Various forms of activation can counteract remaining unemployed or inactive in the labor market and, consequently, can provide the way out of poverty and increase a control of their own lives.

Keywords: unemployment, poverty. 